Available online at GSC Online Press Directory

GSC Biological and Pharmaceutical Sciences

e-ISSN: 2581-3250, CODEN (USA): GBPSC2

Journal homepage: https://www.gsconlinepress.com/journals/gscbps

(RESEARCH ARTICLE)

\title{
Effect of weeding regime on pest infestation, growth and yield of okra (Abelmoschus esculentus L, moench) in Anyigba, Kogi State, Nigeria
}

\author{
Oyewole Charles Iledun* and Obaweda Opeyemi Durojaye \\ Department of Crop Production, Kogi State University, P. M. B. 1008, Anyigba, Kogi State, Nigeria.
}

Publication history: Received on 02 April 2020; revised on 12 April 2020; accepted on 15 April 2020

Article DOI: https://doi.org/10.30574/gscbps.2020.11.1.0083

\begin{abstract}
The study was carried out to evaluate effect of weeding regimes on pest infestation, growth and yield of Okra (Abelmoschus esculentus L. Moench). The experiment was conducted at the Kogi State University Students' Research and Demonstration Farm Anyigba, Kogi State, Nigeria, during 2016 cropping season. The treatment investigated are: i) No weeding, ii) hoe weeding every two weeks, iii) hoe weeding every three weeks, and iv) hoe weeding every four weeks, apportioned to a Random Complete Block Design (RCBD) with five (5) replications. Data were collected on crop growth and yield in addition to pest infestations. Final plant height (8 WAS), leaf number (6 WAS and 8 WAS), leaf area (6 WAS and 8 WAS), crop yield and pest infestation responded significant to weeding regime. Generally, unfavourable conditions created by weed infestation led to observed reduction in crop growth and yield, while encouraging pest incidence. These effects were more pronounced with delayed weeding, where delaying weeding led to reduction in crop growth, yield and yield characters, thus should be avoided in okra production. Weeding every 2 weeks significantly reduced the number of pests, which progressively increased with delay in weeding with the control giving the highest number of pests; as presence of weeds offered the various insect pests habitat as well as protection. The treatment also gave the best crop performance regarding most growth and yield characters, thus recommended.
\end{abstract}

Keywords: Weeds; Okra; Plant height; Number of leaves; Stem girth; Pod yield

\section{Introduction}

Weeds are nutrient-absorbing competitive plants (competing for nutrients, solar radiation and space) possessing characteristics of plentiful growth and reproduction. Their management is the most important aspect of crop production $[1,2]$. Weed management is the ability to manipulate weeds so that they do not seriously interfere with efficient use of the environment in crop production [1]. The goal is to focus the limited weed management resources on the crop growth stages at which weed interference is most critical [2].

As observed earlier, generally weeds are harmful to crops; competing for environmental factors such as nutrients, moisture, light and space [2]. Some produce toxic substances in the root region which can inhibit the germination of crops around them, while some are parasitic in nature. In addition weeds can serve as alternative hosts for pests and diseases of crop plants, for example Acalyptia ciliata which acts as host to root knot nematode. Weeds are important limiting factor in tropical crop production, growing very rapidly and obnoxiously in the rainy season. Uncontrolled weed growth throughout the life of okra could reduce pod yield by $88 \%$ to $93 \%$ [3]. Thus weed infestation is a major problem in the production of okra [4]. However, the extent of weed competition depends on the type of weed species, the severity of weed infestation, the duration of infestation and climatic conditions [4].

Previously researchers have reported that generally, an increase of one kg in weed growth produces a corresponding reduction of one $\mathrm{kg}$ in crop growth $[56,7,8]$, thus this research set out to interrogate: Effect of weeding regime on pest

\footnotetext{
* Corresponding author: Oyewole Charles Iledun
}

Copyright (C) 2020 Author(s) retain the copyright of this article. This article is published under the terms of the Creative Commons Attribution Liscense 4.0. 
infestation, growth and yield of okra (Abelmoschus esculentus l, moench) in Anyigba, Kogi State, Nigeria, with the following objectives: i.) To evaluate effect of weeding regime on the growth, development and pod yield of okra; ii.) To evaluate effect of weeding regime on pest infestation and weed biomass in Anyigba Kogi state, Nigeria.

\section{Material and methods}

\subsection{Experimental area}

The experiment was carried out at the Kogi State University Students' Research and Demonstration Farm, Anyigba (latitude 7o $61 \mathrm{~N}$ and longitude 7o $431 \mathrm{E}$ ), with a bimodal rainfall with peak in July and September, mean annual rainfall range of $1808 \mathrm{~mm}$ (Akande, 2015), temperature ranging from $17 \mathrm{oC}$ to $36.2 \mathrm{oC}$ and relative humidity which averages $65-85 \%$ [9]. The experimental land $(150 \mathrm{~m} 2)$ was ploughed harrowed and ridged, then divided into subplots of sizes measuring $2.4 \mathrm{~m} \times 1.9 \mathrm{~m}$ with ridges spaced $75 \mathrm{~cm}$ apart, and subplots separated by border rows measuring $0.5 \mathrm{~m} .0 \mathrm{kra}$ seeds were sown two per hole to a depth of $2.5 \mathrm{~cm}$ at $75 \mathrm{~cm} \times 30 \mathrm{~cm}$ spacing.

\subsection{Treatment and experimental design}

The treatment investigated are: i) No weeding, ii) hoe weeding every two weeks, iii) hoe weeding every three weeks, and iv) hoe weeding every four weeks, apportioned to a Random Complete Block Design (RCBD) with five (5) replications.

\subsection{Data collection}

\subsubsection{Data collected on okra plant}

- Establishment count: This involves physical counting of establishment stands two weeks after sowing (2WAS).

- In addition, the following growth and yield parameters were collected on $10 \%$ sampled population per plot which were randomly obtained from the net plot and tagged for data collection:

- Plant height taken every two weeks: Involves measuring the length of the plant from the ground level to the epical bud using a meter rule. The results obtained were recorded as means of the sampled population.

- Numbers of leaves taken every two weeks: Involves the physical counting of the leaves. The results were recorded as means of the sampled population as in plant height determination.

- Leaf area taken every two weeks: Involves measuring the length and breadth of the leaf and multiplying by a factor. With the results obtained recorded as means of the sampled population.

- Stem girth taken every two weeks: This involves measuring the plant girth just above the ground level using the Venier caliper and the results recorded as means of the sampled population.

- Number of harvested pods: Determined by physical counting of all harvested pods per sampled population in each plot. The result obtained was recorded as means of the sampled population.

- Weight of harvested pods: Determined by weighing all harvested pods / net plot on a weighing balance.

- Average pod length: Determined using a Venier caliper.

- Fruit Diameter: Determined using a Venier caliper.

\subsubsection{Data collected on weed and pests population}

- Weed sample collection and biomass determination: Samples of weeds in a $15 \mathrm{~cm} \times 15 \mathrm{~cm}$ quadrant were collected, identified and classified based on their floral morphology (broad or narrow), then oven dried at $70^{\circ}$ C for 24 hours.

- Pest samples collection: Samples of pest within $15 \mathrm{~cm}$ x $15 \mathrm{~cm}$ quadrant were collected, identified and classified.

- Data collected were subjected to Analysis of Variance (ANOVA) and means found to be statistically significant at 5 per cent probability were separated using the Least Significant Differences (LSD). Weed and pests data were transformed using the square root transformation before analysis [10]. 


\section{Results and discussion}

\subsection{Effect of weeding regimes on plant height}

At two, four and six weeks after sowing no significant $(\mathrm{P} \geq 0.05)$ effect of weeding regime was observed on plant height (Table 1), though reductions in plant heights were observed as weeding was delayed from weeding every 2 weeks to weeding every 4 weeks. Where weeding every two weeks gave the highest plant height, followed by weeding every three weeks then weeding every four weeks and lastly no weeding. The treatment (weeding regime), however significantly $(\mathrm{P} \leq 0.05)$ influenced height at eight weeks after sowing maintaining the same pattern as seen in earlier weeks. The non significant effects of weeding regime on okra height noticed in the first six weeks gives the time lag required for the competitive effect between the crop and weeds to reach significant level. Key factors that could account for this delay include weed population per unit area, weed vigorousness, weed competitiveness, length of crop-weed interaction, or crop competitiveness.

The observed pattern of a progressive reduction in plant height with delayed weeding is similar to previous findings [11], who reported that plant heights from the un-weeded plots were the lowest. Generally, the unfavourable conditions created by weed infestation must have affected the vitality of okra $[12,13,14]$ leading to the observed reduction in crop height with delay in weeding as the crop struggled with weeds for nutrients, solar radiation and space. Increasing weeding frequencies reduces the length of time the crop is associated with weeds, thus enhancing the potentials of the okra crop, and vice versa [15]. Thus for those crops with longer crop-weed association, it should be expected that the weeds should have more impact on the crop potentials [16] negatively. To reduce such negative impact of weeds on the okra crop, there may be the need to reduce the length of crop-weed interactions $[15,16]$, by increasing the number of weeding conducted.

Table 1 Effect of weeding regime on the plant height $(\mathrm{cm})$

\begin{tabular}{lllll}
\hline Weeding regime & \multicolumn{4}{l}{ Plant height $(\mathbf{c m})$} \\
\cline { 2 - 5 } & 2WAS & 4WAS & 6WAS & 8WAS \\
\hline Control (no weeding) & 4.70 & 9.63 & 13.89 & 16.05 \\
Weeding every 2 weeks & 5.42 & 10.17 & 15.73 & 20.73 \\
Weeding every 3weeks & 5.31 & 9.72 & 15.35 & 19.13 \\
Weeding every 4 weeks & 5.06 & 9.48 & 14.71 & 18.41 \\
F-LSD (0.05) & Ns & Ns & Ns & $1.317^{*}$ \\
\hline Ns = F-LSD not significant at 0.05 percent probability; ${ }^{*}$ F-LSD significant at 0.05 percent probability
\end{tabular}

\subsection{Effect of weeding regimes on stem girth}

Stem girth, which is a measure of a plant's stem width, is an indication of the stem ability to resist lodging resulting from wind or pod bearing [17]. The thicker the girth, the less breakable the stem should be [17]. Results from the study however show that weeding regimes had no significant $(\mathrm{P} \geq 0.05)$ effect on stem girth, thought the control treatment gave the least stem girth at 4,6 and 8WAS (Table 2).

Table 2 Effect of weeding regimes on stem girth $(\mathrm{cm})$

\begin{tabular}{lllll}
\hline Weeding regime & \multicolumn{4}{l}{ Stem girth } \\
\cline { 2 - 5 } & 2WAS & 4WAS & 6WAS & 8WAS \\
\hline Control (no weeding) & 0.62 & 1.02 & 1.32 & 1.46 \\
Weeding every 2 weeks & 0.58 & 1.06 & 1.40 & 1.62 \\
Weeding every 3weeks & 0.54 & 1.14 & 1.38 & 1.58 \\
Weeding every 4 weeks & 0.62 & 1.14 & 1.36 & 1.52 \\
F-LSD (0.05) & Ns & Ns & Ns & Ns \\
\hline \multicolumn{5}{r}{} \\
\hline
\end{tabular}




\subsection{Effect of weeding regimes on number of leaves and leaf area}

Significant $(P \geq 0.05)$ effect of weeding regime was observed on leaf number (Table 3) as well as leaf area (Table 4), at 6 and 8WAS but not at 2 and 4WAS; probably because of the time interval required for the treatment effect to become evident on the okra crop. Generally, reduction in leaf number and leaf area was observed as weeding was delayed for 2 to 4 , with weeding every two weeks giving the highest leaf number as well as leaf area, followed by weeding every three weeks then weeding every four weeks and lastly no weeding. Unfavourable conditions created by weed infestation must have affected the vitality of okra $[12,13,14]$ leading to the observed reduction in leaf number and leaf area with delay in weeding as the crop struggled with weeds.

Table 3 Effect of weeding regimes on number of leaves

\begin{tabular}{lllll}
\hline Weeding regime & \multicolumn{4}{l}{ Number of leaves } \\
\cline { 2 - 5 } & 2WAS & 4WAS & 6WAS & 8WAS \\
\hline Control (no weeding) & 3.27 & 5.40 & 3.80 & 4.33 \\
Weeding every 2 weeks & 3.47 & 5.53 & 4.99 & 6.00 \\
Weeding every 3weeks & 3.20 & 5.47 & 4.47 & 5.33 \\
Weeding every 4 weeks & 3.33 & 5.47 & 4.60 & 5.07 \\
F-LSD (0.05) & Ns & Ns & $0.701^{*}$ & $0.726^{*}$ \\
\hline Ns = F-LSD not significant at 0.05 percent probability; * F-LSD significant at 0.05 percent probability
\end{tabular}

Table 4 Effect of weeding regimes on leaf area $\left(\mathrm{cm}^{2}\right)$

\begin{tabular}{lllll}
\hline Weeding regime & \multicolumn{4}{l}{ Leaf area (cm2) } \\
\cline { 2 - 5 } & 2WAS & 4WAS & 6WAS & 8WAS \\
\hline Control (no weeding) & 7.70 & 44.77 & 58.05 & 83.62 \\
Weeding every 2 weeks & 9.13 & 56.40 & 98.00 & 124.53 \\
Weeding every 3weeks & 8.00 & 48.31 & 89.87 & 111.28 \\
Weeding every 4 weeks & 10.14 & 45.91 & 84.67 & 91.43 \\
F-LSD (0.05) & Ns & Ns & $4.269^{* *}$ & $9.237^{* *}$ \\
\hline Ns = F-LSD not significant at 0.05 percent probability; ${ }^{*}$ F-LSD significant at 0.05 percent probability
\end{tabular}

\subsection{Effect of weeding regimes on pod yield}

Results from the study show that weeding regime had significant $(\mathrm{P} \leq 0.05)$ effect on the number of harvested pods per plant (Table 5), average weight of harvested pods and pod yield/ha, but the treatment had no significant ( $\mathrm{P} \geq 0.05$ ) effect on mean pod diameter and mean pod length. The control had the lowest pod yield per plant (7.40), lowest pod length $(3.90 \mathrm{~cm})$, lowest pod diameter $(2.25 \mathrm{~cm})$ and lowest pod harvested per ha $\left(12.32 \mathrm{t} \mathrm{ha}^{-1}\right)$, while weeding every 2 weeks gave the highest number of harvested pods per plant (20.80), highest pod length $(6.70 \mathrm{~cm})$, pod diameter $(5.75$ $\mathrm{cm})$ and pod yield per ha (20.8 t/ha).

The observation as compared to the control is similar to previous findings [18], where uncontrolled weed growth throughout the life cycle of okra reduced okra marketable fruit between $88 \%$ and $90 \%$ compared with those kept weed free throughout the growth period. While it has been suggested that okra field should be kept weed free throughout growth and production period to obtain maximum pod yield [1]; as keeping weeds beyond three weeks in okra field is reported to caused higher flower abortion, which is capable of reducing fruit formation and consequently lower fruit yield [1]. Observing that most crops have certain range of tolerance to weed competition and length of period in which they are required to be weed free $[18,19,20,21]$. 
Table 5 Effect of weeding regimes on total pod yield of okra

\begin{tabular}{llllll}
\hline Weeding regime & \multicolumn{5}{l}{ Pod yield and yield characters } \\
\cline { 2 - 6 } & $\begin{array}{l}\text { No of pod } \\
\text { Harvested } / \\
\text { Plant }\end{array}$ & $\begin{array}{l}\text { Pod length } \\
(\mathrm{cm})\end{array}$ & $\begin{array}{l}\text { Pod } \\
\text { diameter } \\
(\mathrm{cm})\end{array}$ & $\begin{array}{l}\text { Pod weight } \\
\text { (g plant }{ }^{-1} \text { ) }\end{array}$ & $\begin{array}{l}\text { Pod yield } \\
\left(\mathrm{t} \mathrm{ha}^{-1}\right)\end{array}$ \\
\hline Control (no weeding) & 7.40 & 3.90 & 2.25 & 35.02 & 12.32 \\
Weeding every 2 weeks & 20.80 & 6.70 & 5.75 & 98.04 & 30.09 \\
Weeding every 3weeks & 16.40 & 5.30 & 4.66 & 79.00 & 21.50 \\
Weeding every 4 weeks & 10.20 & 4.80 & 5.17 & 56.20 & 17.32 \\
F-LSD (0.05) & $4.484^{* *}$ & Ns & Ns & $27.736^{* *}$ & $6.091^{* *}$ \\
\hline \multicolumn{5}{c}{ Ns = F-LSD not significant at 0.05 percent probability; ${ }^{*}$ F-LSD significant at 0.05 percent probability }
\end{tabular}

\subsection{Effect of weeding regimes on pest infestation}

The common pests identified were red spider mites, aphids, vegetable leaf miner and white fly. Results from the study shows that weeding regimes had no significant $(\mathrm{P} \geq 0.05)$ effect on pest infestation at 2 WAS, however the treatment significantly influenced pest infestation at 4WAS, 6WAS and 8WAS (Table 6). Weeding every 2 weeks significantly reduced the number of pests, which progressively increased with delay in weeding with the control giving the highest number of pests; as presence of weeds offered the various insect pests habitat as well as protection. Generally the longer the time period between weeding the more the vegetative growth (Table 7); and the more protection provided for insect pests, thus the observed results.

The common weeds identified were Talinum triangulare, Tridax procumben, Cynodon dactylon and Imperata cylindrical.

Table 6 Effect of weeding regimes on pest infestation

\begin{tabular}{lllll}
\hline Weeding regime & \multicolumn{3}{l}{ Pest infestation } \\
\cline { 2 - 5 } & 2WAS & 4WAS & 6WAS & 8WAS \\
\hline Control (no weeding) & 5.20 & 7.80 & 10.14 & 17.20 \\
Weeding every 2 weeks & 3.80 & 5.20 & 4.40 & 5.20 \\
Weeding every 3weeks & 4.80 & 4.20 & 4.60 & 6.00 \\
Weeding every 4 weeks & 5.20 & 6.40 & 6.00 & 9.80 \\
F-LSD (0.05) & Ns & $1.705^{* *}$ & $3.902^{* *}$ & $2.421^{* *}$ \\
\hline Ns = F-LSD not significant at 0.05 percent probability; ${ }^{*}$ F-LSD significant at 0.05 percent probability
\end{tabular}

Table 7 Effect of weeding regimes on weed biomass

\begin{tabular}{|c|c|c|c|}
\hline \multirow[t]{2}{*}{ Weeding regime } & \multicolumn{3}{|c|}{$\begin{array}{l}\text { Weed biomass (g) / } 15 \mathrm{~cm} \times 15 \mathrm{~cm} \\
\text { quadrate }\end{array}$} \\
\hline & 4WAS & 6WAS & 8WAS \\
\hline Control (no weeding) & 9.97 & 74.79 & 203.81 \\
\hline Weeding every 2 weeks & 5.81 & 67.52 & 22.47 \\
\hline Weeding every 3weeks & 7.30 & 81.27 & 28.54 \\
\hline Weeding every 4 weeks & 8.28 & 91.97 & 132.09 \\
\hline F-LSD (0.05) & $1.242^{* *}$ & $5.081^{* *}$ & $17.213^{* *}$ \\
\hline
\end{tabular}




\section{Conclusion}

Weeds are detrimental to crops; competing for nutrients, solar radiation and crop space as well as tasking the farmer's finance, labour and time. This is more so considering their characteristics plentiful growth and reproduction capability. Considering that most farmers are poor, there is the need for adequate weed management taking into cognizance the frequency of weeding operations, which will be most effective. Thus this study was carried to evaluate effect of weeding regimes on pest infestation, growth and yield of Okra (Abelmoschus esculentus L. Moench). Generally, the unfavourable conditions created by weed infestation led to observed reduction in crop growth and yield, while encouraging pest incidence. These effects were more pronounced with delayed weeding, where delaying weeding led to reduction in crop growth and yield formation.

\section{Compliance with ethical standards}

\section{Acknowledgments}

Kogi State University, Anyigba Faculty of Agriculture, Kogi State University, Anyigba.

\section{Disclosure of conflict of interest}

No observed conflict of interest whatsoever.

\section{References}

[1] Akobundu IO. (1987). Weed science in the tropics: Principles and practices, John Wiley and son New York, 522.

[2] Adetiloye PO, Okeleye KA and Olatunde GO. (2006). Principles and practices of crop production, BIIM (Nig) Limited, 153 - 164.

[3] Melifonwu AA. (1999). Effect of varying periods of weed interference on yield of okra (Abelmoschus esculentus) in the humid tropical forest zone of South eastern Nigeria, Agriculture Journal, 30, 15-121.

[4] Rao VS. (1983). Principles of weed science, (2nd edition) Science publishers, Inc. Nee Hampshire, 555.

[5] Torstenson L. (1996). Herbicides in the environments: Proceedings of the second Int'l weed control congress, Copenhagen, $267-273$.

[6] Tollenaar M, Nissanka SP, Aguilera A, Weise SF and Swanton CJ. (1994). Effects of weed Interference and nitrogen on four maize hybrids, Agronomic Journal, 86, 396 - 601.

[7] Gonzales-Ponce R and Salas ML. (1995). Improvement of the growth, grain yield and nitrogen, phosphorus and potassium nutrition of grain corn through weed control, Journal of Plant Nutrition, 18, 2312 - 2324.

[8] Stanojevia M. (2000). Effect of crop density and herbicide application on floristic composition and structure of maize weed community. Journal of Agricultural Science, 45, 7-18.

[9] Akanbi WB, Akande MO and Adediran JA. (2005.) Suitability of composted maize straw and mineral nitrogen fertilizer for tomato production, Journal of vegetable Science, 11(1), 57 - 65.

[10] Gomez KA and Gomez A. (1984). A Statistical procedure for agricultural research, John Wiley and Sons, New York, 680.

[11] Awodoyin RO and Olubode OS. (2009). On-field assessment of critical period of weed interference in okra (Abelmoschus esculentus (L) moench) field in Ibadan, a rain forest -savanna transition eco-zone of Nigeria. Asian Journal of Food Agro Ind, 16, 288-298.

[12] Weiss EA. (1983). Sesame oil seed crops. Longman group, London. In: Yol E and Uzun B. (2012). Geographical pattern of sesame accessions grown under Mediterranean environmental conditions and establishment of a core collection, Crop Sci., 52, $2206-2214$.

[13] Ali MA, Sarwar AMG and Prodhan AKMA. (1999). Effect of water stress on the growth features of different maize (Zea mays L) cultures, Pakistan J. Bot., 31, 455 - 468.

[14] Ndarubu AA, Adejonwo KO, Adegun Y and Chezey F. (2003). Effect of weed control treatment and inter-row spacing on growth of Sesame indicum, Nigeria Journal of Weed Science, 16, 15-22. 
[15] Oyewole CI, Opaluwa H and Omale R. (2012). Response of tomato (Lycopersicum esculentus) growth and yield, to rate of mineral and poultry application in Guinea savannah agro-ecological zone in Nigeria, Journal of Agricultural and Healthcare, 2(2), 45-56.

[16] Oyewole CI, Shuaib H and Musa UT. (2016). Sustainable crop production: growth and yield response of three varieties of groundnut (Arachis hypogeal L.) sown to three weeding regimes and two plant spacing in Anyigba, Kogi State, Nigeria, Journal of International Scientific Publications: Agriculture and Food, 4, 373 - 385.

[17] Oyewole CI and Alemeru JT. (2016). Response of maize crop (growth, development, yield components and yield) to irrigation scheduling and levels in Anyigba, Kogi State, Nigeria. Basic Research Journal of Agricultural Science and Review, 5(6), 90-97.

[18] Adejonwo KO, Ahmed MK, Lagoke STO and Karikari SK. (1989). Effect of variety, nitrogen and period of weed interference on growth and yield of okra (Abelmoschus esculentus (L) moench), Nigeria Journal Weed Sci., 21 (1\&2), $21-28$.

[19] Ayeni AO and Oyekan P. (1992). Weed control in soybean (Glycine max) (Merr) in Nigeria, Tropical Oil Seed Journal, 43-52.

[20] Dada OA and Fayinminu 00. (2007). Influence of cow dung and weeding regimes on yield component of okra (Abelmoschus esculentus L. Moench) in derived savannah agro-ecology Proceedings 25th Annual conference of the Horticultural society of Nigeria held at NIHORT, Ibadan.

[21] Iyagba AG, Onuegbu BA and Ibe AE. (2012). Growth and yield response of okra (Abelmoschus esculentus (L) Moench) varieties on weed interference in Southern- eastern Nigeria, Global J. Sci. Front. Res. Agric. Veterinary Sci., 12(7), $22-29$.

\section{How to cite this article}

Oyewole CI and Obaweda OD. (2020). Effect of weeding regime on pest infestation, growth and yield of okra (Abelmoschus esculentus L, moench) in Anyigba, Kogi State, Nigeria. GSC Biological and Pharmaceutical Sciences, 11(1), 106-112. 